\title{
Az indikátoralapú teljesítményértékelésre épülő forráselosztás hatékonysága Magyarországon a felnőtteket ellátó háziorvosi praxisokban
}

\author{
Pálinkás Anita $^{1}$. Kovács Nóra ${ }^{1}$ - Sipos Valéria ${ }^{1}$. Vincze Ferenc ${ }^{1}$ \\ Papp Magor dr. ${ }^{2}$ - Czifra Árpád dr. ${ }^{1}$ - Ádány Róza dr. ${ }^{1}$ - Sándor János dr. ${ }^{1}$ \\ ${ }^{1}$ Debreceni Egyetem, Népegészségügyi Kar, Megelőző Orvostani Intézet, Debrecen \\ ${ }^{2}$ Nemzeti Népegészségügyi Központ, Budapest
}

Bevezetés: Magyarországon 2009-ben került kialakításra az alapellátási tevékenység értékelését célzó, országosan egységes indikátorrendszer, amely jól kiépített informatikai és jogszabályi háttérrel, illetve finanszírozási vonzattal múködik. A jelenlegi teljesítményértékelési rendszer csak részben (a praxisok földrajzi elhelyezkedése tekintetében) veszi figyelembe azt, hogy a betegek ellátásának hatékonyságát háziorvostól független tényezók is befolyásolják, ugyanakkor az egészségbiztosító csak a háziorvost tudja hatékonyabb munkára ösztönözni többletfinanszírozási eszközével. Célkitüzés: Vizsgálatunk célja a praxisok teljesítményértékelési rendszerének módszertani továbbfejlesztése révén olyan indikátorok kialakítása volt, amelyek alkalmasak a teljesítménynek a háziorvos által nem befolyásolható praxisjellemzőktől független értékelésére.

Módszer: A felnőtteket ellátó háziorvosi praxisok hatékonyságának jellemzésére kidolgozott 12 NEAK-indikátor 2016. júniusi adatait elemeztük. A praxisjellemző́k (az ellátottak kora, neme, a praxisokhoz tartozók relatív iskolázottsága, a praxis megyéje, településtípusa) hatásaitól megtisztított indikátorokat alakítottunk ki. A háziorvosok teljesítményének az országos referenciaszinttől való eltéréseit statisztikai teszttel értékeltük. A jelenlegi és a korrigált indikátorokon alapuló értékelés alapján történő teljesítmények összevetésével elemeztük a monitoringnak és a kapcsolódó többletfinanszírozás felhasználásának megfelelőségét és átalakításának lehetőségeit.

Eredmények: A jelenlegi teljesítményértékelési rendszer a többletfinanszírozás 34,46\%-át hasznosítja a háziorvosi munka hatékonyságának elismerésére, a finanszírozás nagy része a teljesítmények konzerválását szolgálja. Emellett nem képes minden olyan teljesítmény azonosítására, amely lényegesen hatékonyabb az átlagnál, aminek következtében a jelenlegi többletfinanszírozás 8,83\%-ának megfelelő összeg kifizetése marad el. Ha többletfinanszírozásban csak a praxisjellemzők alapján várhatónál szignifikánsan jobb teljesítményt nyújtó praxisok részesülnének, akkor az egy praxisban elérhető havi többletfinanszírozás 176042 Ft-ról 406604 Ft-ra növekedne.

Következtetés: A Nemzeti Egészségbiztosítási Alapkezelő által jelenleg múködtetett értékelési rendszer kiegészítése a praxisjellemzőkre korrigált indikátorok alkalmazásával a jelenlegi monitoringnak és rendelkezésre álló finanszírozás felhasználásának hatékonyságát javítaná.

Orv Hetil. 2019; 160(39): 1542-1553.

Kulcsszavak: alapellátás, finanszírozás, indikátorok, teljesítményértékelés

\section{Resource allocation effectiveness of indicator-based performance monitoring in Hungarian primary care for adults}

Introduction: The indicator-based performance monitoring and pay-for-performance system for Hungarian primary care was established in 2009 , covering the whole country. It is based on a stable legal system and well operating information technology. Although, the health insurance system is able to facilitate the performance improvement only by the financing for general medical practices, the many times modified present system does not take into consideration (apart from the geographical location of practices) factors which determine the performance but cannot be influenced by general practitioners.

Aim: The study aimed at renewing the indicator set and evaluation methodology in order to enable the monitoring to evaluate the performance of general medical practices independent of their structural characteristics. 
Method: Each adult care specific primary care performance indicator from June 2016 covering the whole country has been investigated. Indicators adjusted for structural practice characteristics (age and gender of patients; relative education of people provided; settlement type and county of the practice) have been computed. The difference between adjusted indicators and national reference values has been evaluated by statistical testing. Appropriateness of the present monitoring and financing system has been investigated by comparing the practice level presently applied and adjusted indicators to outline the opportunities to develop the present system.

Results: The present monitoring allocates $34.46 \%$ of pay-for-performance resources for improving the performance of practices. The majority of resources supports the conservation of performance. Furthermore, the present system is not able to identify each practice with better than reference performance, withholding amount corresponding to $8.83 \%$ of pay-for-performance resources. If this financing were restricted to practices with significantly better than reference performance, the maximum of the financing a month in a practice would increase from 176042 HUF (551 EURO) to 406604 HUF (1274 EURO).

Conclusion: Completing the performance monitoring system operated at present by the National Health Insurance Fund of Hungary with indicators adjusted for structural characteristics of the general medical practices, the resource allocation effectiveness could be improved.

Keywords: primary care, financing, indicators, performance evaluation

Pálinkás A, Kovács N, Sipos V, Vincze F, Papp M, Czifra Á, Ádány R, Sándor J. [Resource allocation effectiveness of indicator-based performance monitoring in Hungarian primary care for adults]. Orv Hetil. 2019; 160(39): 15421553

(Beérkezett: 2019. február 28.; elfogadva: 2019. március 24.)

\section{Rövidítések}

COPD $=$ (chronic obstructive pulmonary disease $)$ krónikus obstruktív tüdőbetegség; $\mathrm{HbA}_{\mathrm{lc}}=$ hemoglobin $\mathrm{A}_{\mathrm{lc}} ; \mathrm{ISZB}=$ ischaemiás szívbetegek; ITR = indikátoralapú teljesítményértékelési rendszer; NEAK = Nemzeti Egészségbiztosítási Alapkezelö; OECD $=($ Organisation for Economic Co-operation and Development) Gazdasági Együttmúködési és Fejlesztési Szervezet

Az egészségügyi ellátást monitorozó teljesítményértékelési rendszerek a szolgáltatások hatékonyságát írják le, annak érdekében, hogy támogassák az ellátás javítását célzó fejlesztéseket és motivációt jelentsenek a szükséges változások megtételére $[1,2]$. A helyes monitorozás jól definiált adatgyújtési módszereken, indikátorok meghatározásán és visszajelzéseken alapul. A nemzetközi gyakorlatban az indikátoralapú teljesítményértékelési rendszereket (ITR) elsősorban a szakellátásban alkalmazzák, de több ország (Egyesült Királyság [3, 4], USA [5], Kanada $[6,7]$, Új-Zéland $[8,9]$, Ausztrália $[10,11]$ ) alapellátásában is múködtetnek ITR-t [12]. Az adatfeldolgozás ugyan nem egységes ezekben a rendszerekben, de mindegyikben fontos szerepet kap a szakmai ajánlásoknak megfelelő gondozási (fóként krónikusbeteg-gondozási) és prevenciós (szűrésekkel, védőoltásokkal kapcsolatos) tevékenység értékelése $[5,7,9,11,13,14]$. A monitoring részeként kialakított jelentési rendszerek biztosítják a folyamatos visszajelzést (szolgáltatók, szakpolitika és ellátottak felé) és a javításra szoruló szolgáltatások azonosítását, megteremtik a lehetőségét a szolgáltatók komparatív értékelésének $[1,2]$, ezáltal hozzájárulnak a teljesítmények javulásához [15].
Magyarországon - a Healthcare Effectiveness Data and Information Set [5], a Quality and Outcome Framework $[3,4]$ és az OECD indikátoralapú értékelési rendszere alapján - az alapellátásban végzett munka minőségének és hatékonyságának javítása érdekében 2009-ben került kialakításra az országosan egységes (azóta már többször módosított) indikátorrendszer, melyhez többletfinanszírozási szabályokat is kapcsoltak [16-27]. Az ITR alapját jelentő jogszabály [27] deklarálta, hogy a Nemzeti Egészségbiztosítási Alapkezelő (NEAK) által múködtetett monitoring célja az ellátás hatékonyságának javítása.

A NEAK havonta értékeli a felnőtteket ellátó háziorvosi praxisok tevékenységét $[25,27]$. A feldolgozás során az egyes ellátási események és a szolgáltatás célcsoportjába tartozók számát határozzák meg. Ezt a nyers hányadost használják az elért teljesítmény indikátoraként, és azt vizsgálják, hogy a mutató eléri-e a célértéket. A célérték meghatározása (területi jellemzóket figyelembe véve) megyénként és településtípusonként történik minden indikátorra külön-külön a tárgyévet megelőző évben legjobban teljesítő negyedbe tartozó praxisok eredményei alapján $[25,27]$. Az egyes praxisok annyi indikátorpontot kapnak, ahány indikátor esetében a célértéket elérik.

Az indikátorrendszerre épülő többletfinanszírozás keretében egy évente meghatározott keretösszeget oszt szét a NEAK havonta a praxisok között. A keretösszeg és a praxisok által elért indikátorpontok összegének hányadosa adja az egy indikátorpont után fizetendő összeget. A célértéket elérő praxisok havi többletfinanszírozásának mértéke a gyújtött indikátorpontokkal arányos [25-27]. 
A NEAK kidolgozta és hatékonyan múködteti az ITR jogi, informatikai és finanszírozási hátterét is, azaz biztosítja az infrastrukturális feltételeket ahhoz, hogy a hazai alapellátás fejlesztői jól múködő ITR-re támaszkodhassanak. További jelentős eredménynek tekinthető az is, hogy a háziorvosok megismerték az ITR-t, és elfogadták annak szükségességét [28].

Az értékelési rendszer korlátai (amelyek akadályozzák az ITR céljait, azaz az ellátás javítását célzó fejlesztések támogatását, és csökkentik a háziorvosok motiváltságát a szükséges változások megtételére) a NEAK által kiadott módszertani leírásban és az ITR alapját jelentő jogszabályban egyaránt fellelhetők $[25,27]$. Ezek az alábbiak:

1. Az indikátorkészlet karbantartása és változásokat követő fejlesztése nem megoldott, új indikátorok kidolgozásának nincs folyamatosan múködő mechanizmusa.

2. Az indikátorkészlet csak folyamatindikátorokat tartalmaz.

3. A területi ellátási kötelezettség nélküli praxisokat $(3,5 \%)$ nem vizsgálja.

4. A 200 főnél kisebb praxisokat $(0,3 \%)$ nem vizsgálja.

5. Egyes indikátorok kimaradnak az egyébként vizsgált praxis értékeléséből, ha az indikátorhoz rendelhető célcsoport létszáma az adott praxisban nem éri el a 25 fót.

6. Csak nyers arányszámok kerülnek meghatározásra; a praxis teljesítményét meghatározó, de a háziorvos által nem módosítható tényezőket nem veszi figyelembe.

7. Statisztikai tesztelés hiányában a véletlen ingadozásból adódó, azaz csak jónak tûnő teljesítmény és a véletlen hatásával nem magyarázható, azaz valóban jó teljesítmény nem kerül elkülönítésre a célértéket elérő praxisok esetében.

8. Nem történik meg a gyenge teljesítményt nyújtó praxisok azonosítása.

9. Csak a háziorvosok kapnak visszajelzést a saját indikátorértékeikről.

Összességében, a nyers indikátorok stratifikált célérték elérése alapján a praxisokat az alábbi 3 kategóriába sorolja a NEAK: finanszírozásban részesülő (célérték alapján jól teljesítő), finanszírozásban nem részesülő (célérték alapján gyengébben teljesítő) és nem értékelt praxis.

\section{Célkitüzések}

Természetesen, az indikátoralapú teljesítményértékelési rendszer nem érheti el a célját, ha az indikátorok irrelevánsak, és/vagy az indikátorok értékelése nem kellően körültekintő, és/vagy az eredmények visszajelzése nem kellően hatékony - de tanulmányunkban csak egy aspektussal, az indikátorok értékelésének módszerével foglalkoztunk [1, 2, 29]. A felnőttek alapellátását monitorozó rendszer elég régóta múködik ahhoz, hogy az indikátorok megfelelőségét és az értékelés módszertanát minősíteni lehessen, és a továbbfejlesztésre javaslatokat fogal- mazzunk meg. A NEAK által használt indikátorok definíciójával kapcsolatos problémák ismertek, ezek megoldására azonban csak akkor van lehetőség, ha rendelkezésre állnak érvényes szakmai irányelvek és protokollok, valamint alapellátási tapasztalattal és gyakorlattal rendelkező szakértőket vonnak be az indikátorfejlesztéssel kapcsolatos egyeztetésekbe [28]. Ez jelenleg nem valósul meg, ezért vizsgálatunkban csak az alkalmazott értékelési módszertan minősítésére törekedtünk, és nem vizsgáltuk, hogy az egyes indikátorok definíciója megfelelő-e.

Vizsgálatunk demonstrálni kívánta, hogy (1) lehetséges a jelenleg használt indikátorok megtisztítása a praxisteljesítményt bizonyítottan meghatározó, de a háziorvos által nem befolyásolható tényezők hatásától, (2) az ilyen módon korrigált és statisztikai teszteléssel kiegészített indikátorok képesek kiegészíteni a jelenleg alkalmazott értékelési rendszert a háziorvos személyes teljesítményének leírásával. (3) A továbbfejlesztett és a jelenlegi értékelési rendszer összevetésével vizsgáltuk, hogyan változna meg a felnőtteket ellátó praxisok teljesítményének értékelése és indikátoralapú finanszírozása, ha a korrigált teljesítménymutatók statisztikai értékelésén, azaz a háziorvos személyes teljesítményének értékelésén alapulna a monitoring.

\section{Módszer}

\section{Adatok}

Tanulmányunkban a felnőtteket ellátó háziorvosok prevenciós és gondozási tevékenységét, beutalási és antibiotikumrendelési gyakorlatát monitorozó 12 NEAK-indikátort vizsgáltuk a 2016. júniusi adatok alapján az egész országra kiterjedően (1. táblázat). Az indikátorok alapadatait (az ellátási események és a célcsoportokba tartozók száma) praxisonként, korcsoport és nem szerinti bontásban a NEAK bocsátotta rendelkezésünkre.

\section{Standardizált indikátorok}

A NEAK által rutinszerűen használt indikátorok módszertani továbbfejlesztésére a Svájci Hozzájárulás Program „Egészségügy forrásainak felhasználásával népegészségügyi fókuszú alapellátás-szervezési modellprogram Virtuális Ellátó Központ támogatásával” ( $\mathrm{SH} / 8 / 1)$ pályázat keretében került sor. A fejlesztés során a rendelkezésre álló adatok intenzívebb hasznosítására törekedtünk olyan módszerek kialakításával, amelyek célzott adatgyüjtést nem igényelnek. Az SH/8/1 projekt keretében elvégeztük azokat az elemzéseket, amelyek vizsgálták, hogy a praxisszintû indikátorok értékét milyen faktorok befolyásolják. A vizsgált tényezők (az ellátottak neme és életkora, a praxishoz tartozó terület szocioökonómiai státuszát jellemző relatív iskolázottság, a praxis elhelyezkedése és a praxisközpont településtípusa, a praxis mérete, valamint a praxis betöltetlensége) közül azokat vettük 
1. táblázat |A felnőtteket ellátó háziorvosi szolgálatok indikátoralapú teljesítményértékelési rendszerében használt indikátorok

\begin{tabular}{|c|c|c|}
\hline Indikátor & Az indikátor célcsoportja & Adatok \\
\hline $\begin{array}{l}\text { Influenza elleni védőoltásban részesülő } 65 \\
\text { év felettiek }\end{array}$ & 65 év feletti bejelentkezett biztosítottak & $\begin{array}{l}\text { Összesített érték az elmúlt } 12 \text { hónap } \\
\text { alapján }\end{array}$ \\
\hline $\begin{array}{l}\text { Mammográfiás szûrésen részt vett } 45-65 \\
\text { éves nők }\end{array}$ & 45-65 éves nők & $\begin{array}{l}\text { Összesített érték az elmúlt } 24 \text { hónap } \\
\text { alapján }\end{array}$ \\
\hline $\begin{array}{l}\text { Hypertonia kezelésére szolgáló gyógyszert } \\
\text { kiváltó } 40-54 \text { év közöttiek }\end{array}$ & 40-54 év közötti bejelentkezett biztosítottak & $\begin{array}{l}\text { Összesített érték az elmúlt } 12 \text { hónap } \\
\text { alapján }\end{array}$ \\
\hline $\begin{array}{l}\text { Hypertonia kezelésére szolgáló gyógyszert } \\
\text { kiváltó 55-69 év közöttiek }\end{array}$ & 55-69 közötti bejelentkezett biztosítottak & $\begin{array}{l}\text { Összesített érték az elmúlt } 12 \text { hónap } \\
\text { alapján }\end{array}$ \\
\hline $\begin{array}{l}\text { Szérumkreatinin-szint meghatározásán } \\
\text { részt vett hypertoniás betegek }\end{array}$ & $\begin{array}{l}\text { Hypertoniás betegek (az elmúlt } 12 \text { hónapban legalább } \\
\text { 4-szer C02, C03, C04, C05, C07, C08, C09 ATC kódú } \\
\text { gyógyszert kiváltók) }\end{array}$ & $\begin{array}{l}\text { Összesített érték az elmúlt } 12 \text { hónap } \\
\text { alapján }\end{array}$ \\
\hline $\begin{array}{l}\text { Vérzsírvizsgálaton részt vett cukorbetegek } \\
\text { és/vagy hypertoniás betegek }\end{array}$ & $\begin{array}{l}\text { Diabetes mellitusban és/vagy hypertoniában szenvedő } \\
\text { betegek (az elmúlt } 12 \text { hónapban legalább 4-szer A10 és/ } \\
\text { vagy C02, C03, C04, C05, C07, C08, C09 ATC kódú } \\
\text { gyógyszert kiváltók) }\end{array}$ & $\begin{array}{l}\text { Összesített érték az elmúlt } 12 \text { hónap } \\
\text { alapján }\end{array}$ \\
\hline $\begin{array}{l}\text { Ischaemiás szívbetegek közül a rendszere- } \\
\text { sen béta-blokkolót szedők }\end{array}$ & $\begin{array}{l}\text { Infarktuson (AMI) vagy coronariabypass-mútéten } \\
\text { (CABG) vagy szívkatéteres tágításon (PTCA) átesett } \\
\text { betegek }\end{array}$ & $\begin{array}{l}\text { Összesített érték az elmúlt } 12 \text { hónap } \\
\text { alapján }\end{array}$ \\
\hline $\begin{array}{l}\text { Hemoglobin } \mathrm{A}_{1 \mathrm{c}} \text {-vizsgálaton részt vett } \\
\text { cukorbetegek }\end{array}$ & $\begin{array}{l}\text { Diabetes mellitusban szenvedő betegek (az elmúlt } 12 \\
\text { hónapban legalább } 4 \text {-szer Al0 ATC kódú gyógyszert } \\
\text { kiváltók) }\end{array}$ & $\begin{array}{l}\text { Összesített érték az elmúlt } 12 \text { hónap } \\
\text { alapján }\end{array}$ \\
\hline $\begin{array}{l}\text { Szemészeti vizsgálaton részt vett } \\
\text { cukorbetegek }\end{array}$ & $\begin{array}{l}\text { Diabetes mellitusban szenvedő betegek (az elmúlt } 12 \\
\text { hónapban legalább 4-szer Al0 ATC kódú gyógyszert } \\
\text { kiváltók) }\end{array}$ & $\begin{array}{l}\text { Összesített érték az elmúlt } 12 \text { hónap } \\
\text { alapján }\end{array}$ \\
\hline $\begin{array}{l}\text { Légzésfunkciós vizsgálaton részt vett } \\
\text { COPD-s betegek }\end{array}$ & $\begin{array}{l}\text { COPD-s betegek (az elmúlt } 12 \text { hónapban legalább } \\
\text { 3-szor R03 ATC kódú gyógyszert kiváltók és a } \\
\text { COPD-vel diagnosztizáltak köre) }\end{array}$ & $\begin{array}{l}\text { Összesített érték az elmúlt } 12 \text { hónap } \\
\text { alapján }\end{array}$ \\
\hline $\begin{array}{l}\text { Járóbeteg-szakellátásban háziorvosi } \\
\text { beutalóval megjelentek }\end{array}$ & Bejelentkezett biztosítottak & Havi átlag az elmúlt 6 hónap alapján \\
\hline $\begin{array}{l}\text { A háziorvos által felírt, kiváltott antibioti- } \\
\text { kumvények }\end{array}$ & 18 év feletti bejelentkezett biztosítottak & Havi átlag az elmúlt 12 hónap alapján \\
\hline
\end{tabular}

figyelembe a korrigált indikátorok kialakításakor, amelyek a legtöbb indikátor értékében befolyásoló faktornak bizonyultak. (Az SH/8/1 projekt eredménytermékei - a szerzőktől független okokból - sajnos nem érhetők el, ezért azokra nem tudunk hivatkozni.) Ezek alapján az ellátott felnőttek korára és nemére, a relatív iskolázottságra, továbbá a praxis elhelyezkedésére és a praxisközpont településtípusára korrigáltunk az elemzésekben [30].

A praxisjellemzők alapján számolt országos referenciagyakoriságokat és a praxisban az adott indikátorral leírt ellátás célcsoportjába tartozók számát felhasználva határoztuk meg praxisonként a várható ellátási események számát. A praxisban ténylegesen megfigyelt ellátási események számát és a praxisjellemzők alapján várt értéket egymáshoz viszonyítva, standardizált hányadost számítottunk minden indikátorra minden praxisban. A teljesítmények referenciaszinttől való szignifikáns és véletlennel magyarázható eltérésének elkülönítésére mid-p tesztet alkalmaztunk [31], amelynek alapján a praxisokat indikátoronként az átlagnál jobb, az átlagnál gyengébb és az átlagnak megfelelő teljesítményű kategóriákba soroltuk.
A kialakított módszertannal így értékelhető, hogy egy adott praxis a hasonló adottságú praxisok között milyen eredményességgel múködik.

\section{A monitoring hatékonysága}

A NEAK rutinszerüen alkalmazott monitoringjában használt három csoportot (a célérték alapján jól teljesítő, a célérték alapján gyengébben teljesítő és nem értékelt praxis) mindegyik indikátor esetében tovább bontottuk a standardizált indikátorok statisztikai értékelése alapján (az átlagnál jobban, az átlagnak megfelelően és az átlagnál gyengébben teljesítő praxis). Összességében 9 csoportba soroltuk a praxisokat (2. táblázat).

\section{A forráselosztás hatékonysága}

A jelenleg alkalmazott monitoring alapján végzett finanszírozás megfelelőségének értékeléséhez indikátoronként számítottuk, hogy a praxisjellemzőkkel korrigált standardizált indikátor alapján az átlagnál szignifikánsan 


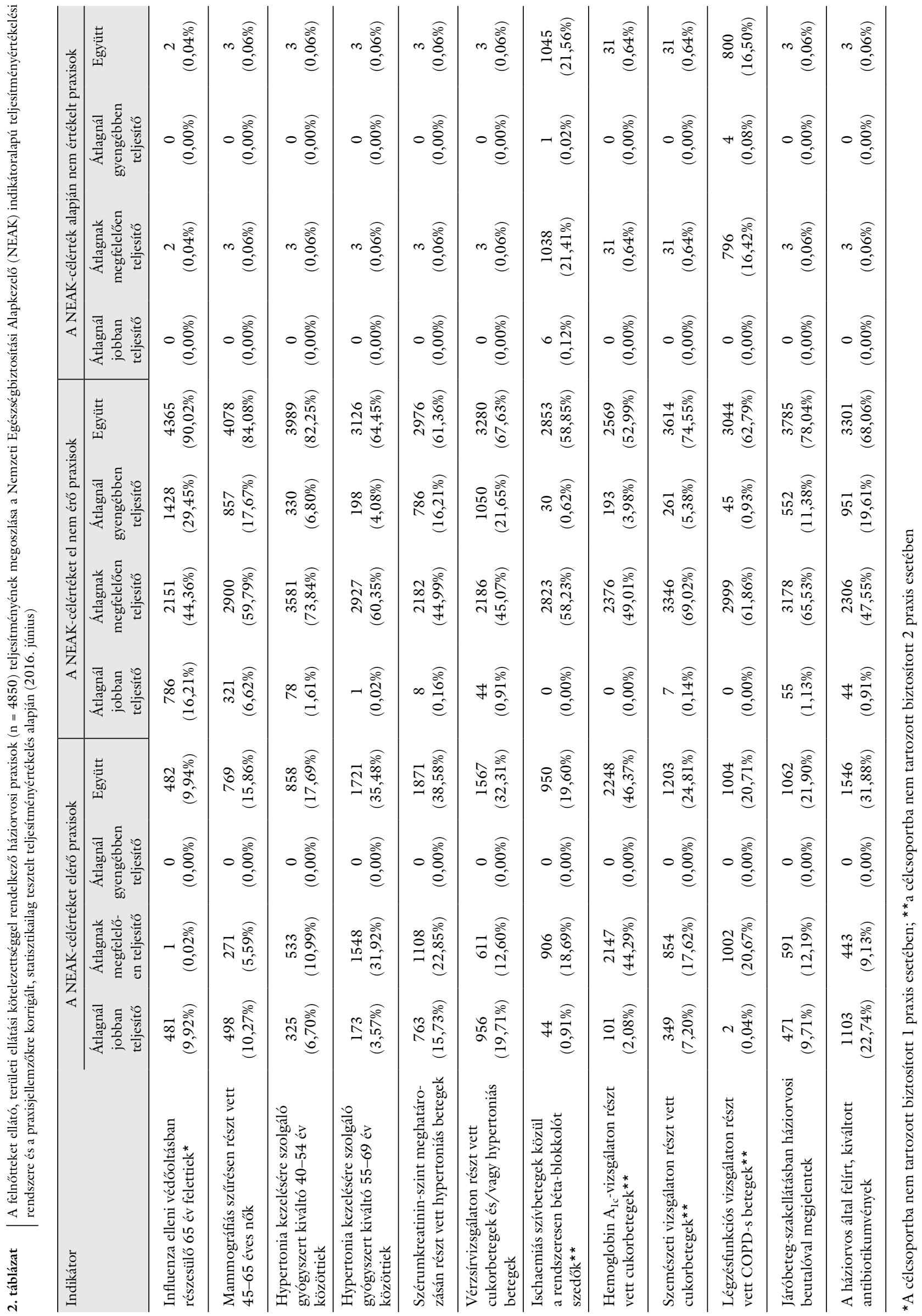


jobb teljesítményt nyújtó praxisoknak adott többletfinanszírozás hányad részét teszi ki az adott indikátor esetében összességében kifizetett támogatási összegnek. A finanszírozási rendszer hatékonyságát összességében a 12 indikátorra, hasonló módon számított aggregált indikátorral írtuk le.

Elmaradt kifizetésnek azt a helyzetet definiáltuk, amelyben a praxis a praxisjellemzókkel korrigált standardizált indikátor alapján az átlagnál szignifikánsan jobb teljesítményt nyújtott, de (1) a jelenlegi értékelési rendszerben nem érte el a célértéket és ezért nem részesült többletfinanszírozásban, vagy (2) a minimális esetszámra vonatkozó feltételeknek nem felelt meg, és ezért kiszámításra sem került az indikátor értéke. Az egy indikátorpont után egyébként kapható összeg jelentette az elmaradt finanszírozást. Indikátoronként és a 12 indikátorra együttesen is meghatároztuk az elmaradt kifizetés és a jelenlegi rendszerben kifizetett összegek arányát (3. táblázat).

\section{A standardizált indikátorokra alapozott finanszírozás modellezése}

A standardizált indikátorokra alapozott finanszírozás alkalmazásának hatását a rendelkezésre álló keretösszegek újraosztásával vizsgáltuk. A többletfinanszírozási keretösszeg és a standardizált értékelés szerint az átlag feletti teljesítményű praxisok száma alapján számítottuk az egy

3. táblázat |A felnőtteket ellátó háziorvosok indikátoralapú teljesítményértékelési rendszeréhez kapcsolódó finanszírozás megoszlása a praxisok teljesítménye alapján (2016. június)

\begin{tabular}{|c|c|c|c|c|c|c|c|c|}
\hline \multirow[t]{2}{*}{ Indikátor } & \multicolumn{3}{|c|}{$\begin{array}{l}\text { Finanszírozásban részesülő praxisokra } \\
\text { fordított összeg (millió Ft) }\end{array}$} & \multirow{2}{*}{$\begin{array}{l}\text { Megfelelő } \\
\text { forrás- } \\
\text { allokáció* }^{*}\end{array}$} & \multicolumn{3}{|c|}{$\begin{array}{c}\text { Elmaradt finanszírozás (millió Ft) } \\
\text { (átlagnál jobban teljesítő) }\end{array}$} & \multirow[t]{2}{*}{$\begin{array}{l}\text { Elmaradt } \\
\text { kifizetés }\end{array}$} \\
\hline & $\begin{array}{l}\text { Átlagnál } \\
\text { jobban } \\
\text { teljesítő }\end{array}$ & $\begin{array}{l}\text { Átlagnak } \\
\text { megfelelően } \\
\text { teljesítő }\end{array}$ & Összesen & & $\begin{array}{l}\text { Finanszíro- } \\
\text { zásban nem } \\
\text { részesülö } \\
\text { praxisok }\end{array}$ & $\begin{array}{l}\text { Nem } \\
\text { értékelt } \\
\text { praxisok }\end{array}$ & Összesen & \\
\hline $\begin{array}{l}\text { Influenza elleni védőoltásban } \\
\text { részesülő } 65 \text { év felettiek }\end{array}$ & 7,06 & 0,01 & 7,07 & $99,86 \%$ & 11,53 & 0 & 11,53 & $5,14 \%$ \\
\hline $\begin{array}{l}\text { Mammográfiás szűrésen részt } \\
\text { vett } 45-65 \text { éves nők }\end{array}$ & 7,31 & 3,98 & 11,28 & $64,80 \%$ & 4,71 & 0 & 4,71 & $2,10 \%$ \\
\hline $\begin{array}{l}\text { Hypertonia kezelésére szolgáló } \\
\text { gyógyszert kiváltó } 40-54 \text { év } \\
\text { közöttiek }\end{array}$ & 4,77 & 7,82 & 12,59 & $37,89 \%$ & 1,14 & 0 & 1,14 & $0,51 \%$ \\
\hline $\begin{array}{l}\text { Hypertonia kezelésére szolgáló } \\
\text { gyógyszert kiváltó 55-69 év } \\
\text { közöttiek }\end{array}$ & 2,54 & 22,71 & 25,25 & $10,06 \%$ & 0,01 & 0 & 0,01 & $0,01 \%$ \\
\hline $\begin{array}{l}\text { Szérumkreatinin-szint } \\
\text { meghatározásán részt vett } \\
\text { hypertoniás betegek }\end{array}$ & 11,19 & 16,25 & 27,45 & $40,77 \%$ & 0,12 & 0 & 0,12 & $0,05 \%$ \\
\hline $\begin{array}{l}\text { Vérzsírvizsgálaton részt vett } \\
\text { cukorbetegek és/vagy } \\
\text { hypertoniás betegek }\end{array}$ & 14,02 & 8,96 & 22,99 & $60,98 \%$ & 0,65 & 0 & 0,65 & $0,29 \%$ \\
\hline $\begin{array}{l}\text { Ischaemiás szívbetegek közül } \\
\text { a rendszeresen béta-blokkolót } \\
\text { szedők }\end{array}$ & 0,65 & 13,29 & 13,94 & $4,66 \%$ & 0 & 0,09 & 0,09 & $0,04 \%$ \\
\hline $\begin{array}{l}\text { Hemoglobin } \mathrm{A}_{\mathrm{lc}} \text {-vizsgálaton } \\
\text { részt vett cukorbetegek }\end{array}$ & 1,48 & 31,50 & 32,98 & $4,49 \%$ & 0 & 0 & 0 & $0,00 \%$ \\
\hline $\begin{array}{l}\text { Szemészeti vizsgálaton részt } \\
\text { vett cukorbetegek }\end{array}$ & 5,12 & 12,53 & 17,65 & $29,01 \%$ & 0,10 & 0 & 0,10 & $0,05 \%$ \\
\hline $\begin{array}{l}\text { Légzésfunkciós vizsgálaton részt } \\
\text { vett COPD-s betegek }\end{array}$ & 0,03 & 14,70 & 14,73 & $0,20 \%$ & 0 & 0 & 0 & $0,00 \%$ \\
\hline $\begin{array}{l}\text { Járóbeteg-szakellátásban } \\
\text { háziorvosi beutalóval meg- } \\
\text { jelentek }\end{array}$ & 6,91 & 8,67 & 15,58 & $44,35 \%$ & 0,81 & 0 & 0,81 & $0,36 \%$ \\
\hline $\begin{array}{l}\text { A háziorvos által felírt, kiváltott } \\
\text { antibiotikumvények }\end{array}$ & 16,18 & 6,50 & 22,68 & $71,34 \%$ & 0,65 & 0 & 0,65 & $0,29 \%$ \\
\hline$\ddot{O ̈ s s z e s e n}$ & 77,25 & 146,92 & 224,17 & $34,46 \%$ & 19,72 & 0,09 & 19,80 & $8,83 \%$ \\
\hline
\end{tabular}

*Az átlagnál jobban teljesítő praxisokra fordított összeg aránya a jelenlegi teljes finanszírozásból

\# Az átlagnál jobban teljesítő, de nem finanszírozott vagy nem értékelt praxisokra fordítandó összeg aránya a jelenlegi teljes finanszírozásból

Az egy indikátorpontra jutó finanszírozás összege $14670 \mathrm{Ft}$ 
indikátorpont után járó összeget. Ez alapján praxisonként és a rendszer egészében vizsgáltuk, hogy miként rendeződne át a finanszírozás, ha a jelenlegi rendszert a standardizált indikátorokon alapuló finanszírozással helyettesítenénk.

\section{Eredmények}

A 2016. júniusi adatok alapján a 4850 területi ellátási kötelezettséggel múködő praxis 7484353 felnőtt ellátását biztosította. Az influenza elleni védőoltás indikátor esetén 1 praxisnál, az ischaemiás szívbetegek (ISZB) béta-blokkoló kezelésére, a diabetesesek $\mathrm{HbA}_{\mathrm{lc}}$ - és szemészeti vizsgálatára, valamint a krónikus obstruktív tüdőbetegségben (COPD) szenvedők gondozására vonatkozó indikátorok esetén 2-2 praxisnál nem tartozott biztosított a célcsoportba. Így ezeknél az indikátoroknál 4849, illetve 4848 praxis teljesítményét tudtuk vizsgálni (2. táblázat).

Az ISZB és a COPD-s betegek gondozásával kapcsolatos indikátornál volt a leggyakoribb (a praxisok 21,56\%-a és 16,50\%-a) az értékelésből történő kizárás amiatt, hogy az indikátor célcsoportjába tartozók létszáma nem érte el a NEAK által meghatározott 25 fős limitet. A többi indikátornál ez $1 \%$ alatt volt (2. táblázat).

A finanszírozásban részesült (azaz a célérték alapján jól teljesítő) praxisok között a korrigált értékelés alapján is átlag feletti teljesítményű praxisok aránya nagy indikátoronkénti variabilitást mutatott. Az eltérések hátterében álló okok vizsgálata további elemzést igényelne, a jelen tanulmány terjedelmi korlátai azonban nem teszik lehetővé ennek tárgyalását, és csak a praxisok finanszírozásával kívántunk foglalkozni. A legkisebb hatékonyság a COPDgondozás $(0,20 \%)$, a legnagyobb hatékonyság az influenza elleni védőoltás esetében $(99,86 \%)$ volt megfigyelhető. A medián hatékonyság 39,33\% volt (3. táblázat).

4 indikátornál a praxisok több mint $20 \%$-a úgy részesült többletfinanszírozásban, hogy a standardizált indikátor alapján teljesítményük nem tért el az átlagtól $\left(\mathrm{HbA}_{\mathrm{lc}}\right.$ a praxisok 44,29\%-a, hypertoniagondozás 55-69 éveseknél 31,92\%, szérumkreatinin-vizsgálat $22,85 \%$ és COPD-gondozás 20,67\%) (2. táblázat).

Egyetlen indikátor esetében sem fordult elő, hogy olyan praxis részesült volna többletfinanszírozásban, amely a standardizált mutatón alapuló értékelés szerint átlag alatti teljesítményt nyújtott volna (2. táblázat).

$\mathrm{Az}$ influenza elleni védőoltás indikátornál 786 praxis $(16,21 \%)$ a standardizált indikátor szerinti átlag feletti teljesítménye ellenére sem részesült finanszírozásban, mert a célértéket nem sikerült elérnie. A mammográfiánál ugyanez a praxisok 6,62\%-ánál (321 praxis) fordult elő (2. táblázat).

\section{A jelenlegi finanszírozás megfelelösége}

A 12 indikátor alapján összesen 224,17 millió forint $(\mathrm{MFt})$ került szétosztásra a célérték alapján kiemelésre került praxisok között 2016. júniusban, amikor az egy indikátorpontra jutó finanszírozás összege $14670 \mathrm{Ft}$ (egy praxis maximálisan elérhető bevétele a 12 indikátor után $176042 \mathrm{Ft}$ ) volt. A vizsgált 4850 praxisból 350 $(7,22 \%)$ egyetlen indikátor után sem kapott finanszírozást, továbbá nem volt olyan praxis, amely mind a 12 indikátor alapján indikátorpontban és ezért maximális díjazásban részesült volna. A praxisok által elért átlagos pontérték 3, az indikátorok után járó átlagos praxisbevétel 46222 Ft volt.

A finanszírozás 34,46\%-a $(77,25 \mathrm{MFt})$ került a standardizált mutató alapján is átlag feletti teljesítményt nyújtó praxisokhoz. Mindössze 4 indikátor esetében volt $50 \%$ feletti a forráselosztás hatékonysága ebból a szempontból (a lipidstátusz ellenőrzése 60,98\%; mammográfia 64,80\%; antibiotikumkiváltás 71,34\%; influenza elleni védőoltás 99,86\%). Az indikátorrendszerben kifizetett teljes összeg $65,54 \%$-a (146,92 MFt) olyan praxisokhoz került, amelyek teljesítménye a standardizált mutatók alapján nem tért el szignifikánsan az átlagtól. A legkevésbé hatékony ebből a szempontból a COPD-gondozás indikátor monitoringja volt, ahol a kifizetésre került öszszeg 99,80\%-a a standardizált indikátor alapján átlagos teljesítményü praxisokhoz került (3. táblázat).

Az elmaradt finanszírozás mértéke (azaz a standardizált indikátorok szerint átlagon felüli, de célérték alatti teljesítményt nyújtó vagy nem értékelt praxisokra jutó elmaradt kifizetés) az influenza elleni védőoltás (5,14\%) és a mammográfia esetében $(2,10 \%)$ volt jelentős. Csak két indikátornál $\left(\mathrm{HbA}_{\mathrm{lc}}\right.$ és COPD-gondozás) nem volt olyan praxis, amelynek a teljesítménye a standardizált mutatókon alapuló értékelés szerint jobb volt az átlagnál, de nem részesült finanszírozásban. A többi indikátornál $1 \%$ alatt volt az elmaradt kifizetés aránya. Az alacsony esetszámra való tekintettel ki nem számított indikátorértékek miatt csak az ISZB-gondozás esetében maradt el az átlagnál jobban teljesító praxisok finanszírozása. Összességében a jelenlegi finanszírozás 8,83\%-ának megfelelő összeg (19,80 MFt) nem került a jobban teljesítő praxisokhoz. Ebből 19,72 MFt az átlag felett teljesítő, de finanszírozásban nem részesült praxisok esetében, 0,09 MFt a szintén az átlagnál jobban teljesító, de a kizárási kritériumok miatt nem értékelt praxisok esetében maradt el (3. táblázat).

\section{A standardizált indikátoralapú monitorozás batása a finanszírozásra}

A standardizált mutatókon alapuló értékelés szerint a 12 indikátor esetében összesen 6616 esetben lehetett átlag feletti praxisteljesítményt megállapítani. Ebből 6 indikátorpontot olyan praxisok kaptak, amelyek a jelenlegi, célértékelérésen alapuló rendszerben nem voltak értékelhetők, 1344-et olyanok, amelyek nem érték el a célértéket, így nem részesültek finanszírozásban, és 5266 indikátorpontot olyanok, amelyek a jelenlegi rendszer szerint is kaptak díjazást (2. táblázat). Ha a 2016 júniusában kifi- 
zetett teljes többletfinanszírozást $(224,17 \mathrm{MFt})$ csak a kortól, nemtől, iskolázottságtól és területi elhelyezkedéstől függetlenül is jobb teljesítményt nyújtó praxisok között osztották volna szét, akkor az egy indikátorra jutó finanszírozás összege 14670 Ft-ról 33884 Ft-ra emelkedett volna.

A jelenlegi rendszerben nem értékelt szolgálatokat összesen 0,20 MFt illette volna meg a standardizált indikátoraik alapján (1.ábra).

Az átlagos teljesítményú, de a jelenlegi monitoring által premizált praxisok, melyek összesen 146,92 MFt-ot kaptak, a standardizált értékelés szerint nem részesültek volna kifizetésben.

A jelenlegi és a standardizált monitoring szerint is premizálandó praxisok a jelenlegi 77,25 MFt több mint két- szeresét, 178,43 MFt kaphatták volna a standardizált indikátorokon alapuló monitoring alapján (1. ábra).

Azok a praxisok, amelyek a jelenlegi értékelés szerint nem részesültek finanszírozásban, pedig a standardizált indikátorok alapján átlag feletti teljesítményt nyújtottak, 45,54 MFt összegű kifizetést kaphattak volna a standardizált módszertannal számított indikátorpontok alapján (1. ábra).

\section{Megbeszélés}

A felnőtteket ellátó háziorvosi praxisok NEAK által stratifikált módon meghatározott nyers indikátorokon alapuló értékelése és ugyanezen indikátorok statisztikai teszttel értékelt praxisjellemzőkre (korra, nemre, iskolá-

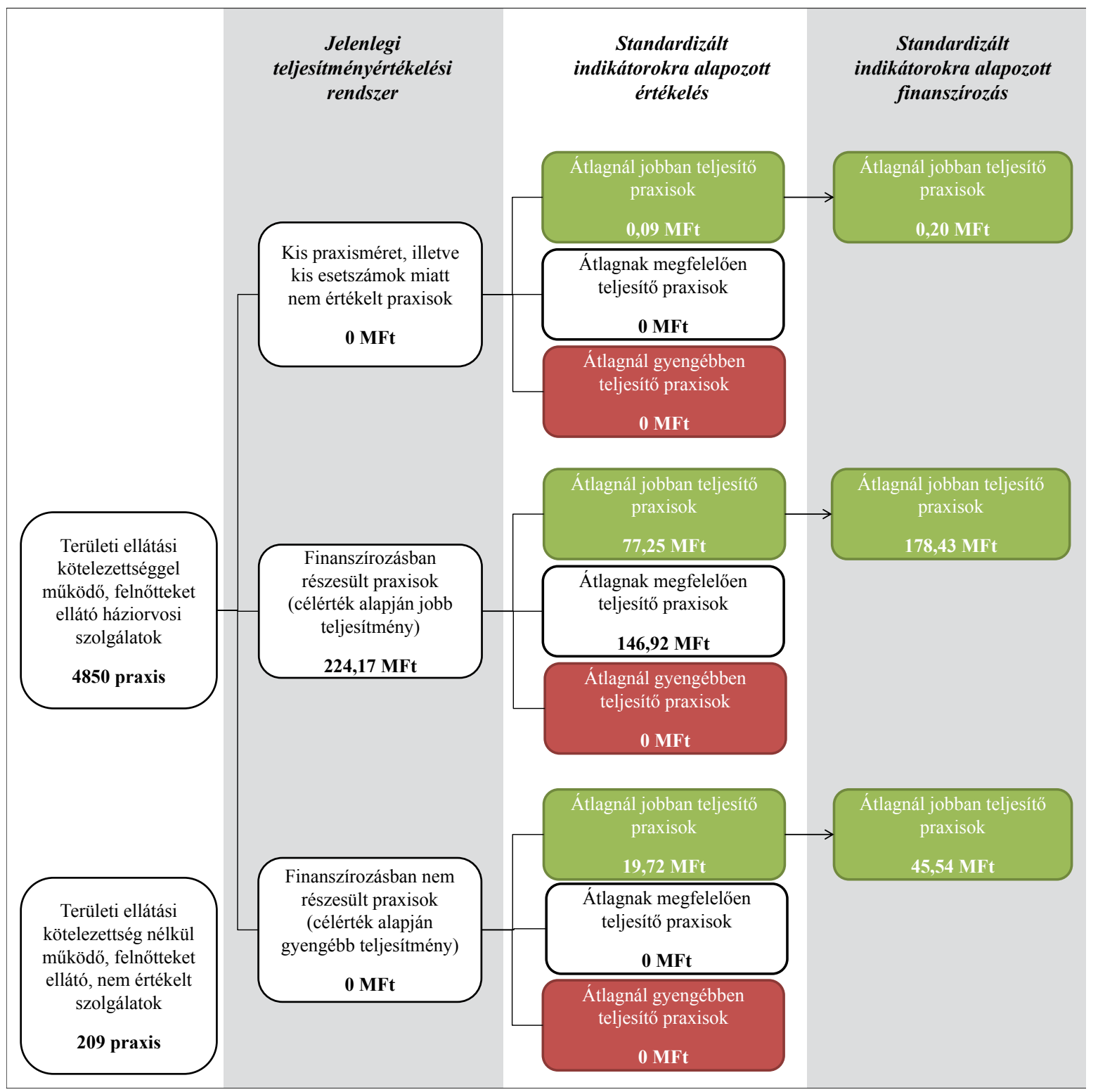

| Az indikátoralapú teljesítményértékelési rendszerhez kapcsolódó 1 hónapra eső többletfinanszírozás (millió Ft; MFt) és a praxisjellemzőkkel korrigált, statisztikailag tesztelt indikátorokra alapozott finanszírozás kapcsolata (2016. június) 
zottságra, megyére, illetve településtípusra) korrigált standardizált indikátorokon alapuló értékelésének összevetése alapján a jelenlegi ITR a ráépülő többletfinanszírozás 34,46\%-át hasznosítja a háziorvosi munka hatékonyságának javítása érdekében. A többletfinanszírozás harmada jut olyan praxisokhoz, ahol a praxisjellemzők alapján várható teljesítménynél lényegesen jobban teljesítenek, azaz indokolt a premizálásuk. A finanszírozás 65,54\%-át átlagos teljesítményü praxisok kapják, amelyeknél a praxis viszonylag kedvező szociodemográfiai összetétele és/vagy elhelyezkedése miatt az átlagos háziorvosi teljesítmény is elég a nyers indikátorok célérték fölé emeléséhez. Ezeknél a praxisoknál a jelenlegi ITR alapvetően a kedvező praxisjellemzők hatását finanszírozza, ezáltal az ellátás hatékonyságának javítását nem ösztönzi.

A jelenlegi ITR nem képes azonosítani az összes olyan praxist, ahol a praxisjellemzők alapján várható teljesítményhez képest lényegesen magasabb hatékonyságot érnek el, és emiatt a többletfinanszírozás 8,83\%-át nem fizeti ki a NEAK a háziorvosoknak. Azaz a jelenlegi ITR nem ismeri el azoknak a nehéz körülmények (kedvezőtlenebb szociodemográfiai összetétel és/vagy elhelyezkedés) között dolgozó háziorvosoknak a teljesítményét, akik nem tudták teljes mértékben kompenzálni a hátrányos helyzetből adódó következményeket, ami a nehéz munkakörülmények között múködő praxisok álláshelyeinek betöltése ellen hat. Külön említendő hatása ennek a méltányosságot nélkülöző forrásallokációnak, hogy egy átlagos teljesítményű, de a jelenlegi ITR alapján többletfinanszírozásra nem jogosult praxis háziorvosa számára nem érthető, hogy egy másik átlagos teljesítményű praxis miért kap többletjuttatást, amikor a két praxisban a háziorvos munkája hasonló módon zajlik.

A standardizált indikátorok segítségével azonosíthatók azok a praxisok, ahol a teljesítmények lényegesen gyengébbek, mint az a praxisjellemzők alapján várható lenne. Ezeknél a praxisoknál külön vizsgálatot igényelne a valószínú ok feltárása, hiszen az alacsony hatékonyságú ellátás árát az ellátottak fizetik meg. Az esetek többségében, vélhetően, speciális (a feltárt speciális okoknak megfelelő) praxistámogatásra volna szükség a legalább átlagos szintű ellátás biztosítása érdekében.

Elemzésünk alapján, ha kiegészítenék a jelenlegi ITR-t standardizált indikátorok statisztikai értékelésével (hasznosítva más országok, például az angliai finanszírozási rendszer tapasztalatait [4]), akkor ez:

1. megszüntetné az átlagos teljesítmények indokolatlan - és az ITR teljesítményjavító hatását aláásó - finanszírozását,

2. megszüntetné az azonos háziorvosi teljesítményt nyújtók eltérő finanszírozásából adódó feszültségeket,

3. megmutatná, hogy mely praxisok helyzete igényelne többletfigyelmet,
4. megszüntetné azt a helyzetet, hogy a többletfinanszírozás 1/3-a a teljesítmények növelésének, 2/3-a a teljesítmények konzerválásának irányába hat.

A standardizált indikátorok használatának bevezetését modellező adatok szerint, ha csak azok a praxisok kerülnének premizálásra, amelyek a praxis adottságaitól függetlenül, alapvetően a háziorvosi tevékenységnek köszönhetően tudnak hatékonyabb ellátást biztosítani betegeik számára, akkor az egy indikátorpontra eső többletfinanszírozás összege 14670 Ft-ról 33884 Ft-ra emelkedne, ami az angliai háziorvosok 1 indikátorpontra jutó bevételének 22,45\%-a helyett már $52,07 \%$-ot jelentene [32]. A praxisok által elvileg elérhető maximális havi ITR-alapú többletfinanszírozás pedig 176042 Ft helyett 406604 Ft-ra növekedne, ami valószínúleg erősítené a háziorvosok hatékonyabb ellátásra való törekvését. A tapasztalatok szerint egy ITR akkor múködik hatékonyan, ha a kapcsolódó finanszírozás eléri a praxis teljes bevételének 10\%-át [33-35]. Bár ez nem tekinthető határozott küszöbnek, hiszen például Új-Zélandon annak ellenére múködik hatékonyan a monitoring, hogy az alapellátás teljes bevételének mindössze 1\%-a származik ITR-ből [8, 35]. A 2018. évi kormányzati előirányzat szerint az indikátorok után járó díjazás a háziorvosi, háziorvosi ügyeleti ellátásra fordított összeg 3,55\%-át teszi ki Magyarországon [36]. Az egy praxisra jutó átlagos teljes bevétel (fix összegû díjazás, területi kiegészítő díjazás, teljesítményarányos díjazás [„kártyapénz”], eseti ellátás díjazása, jogviszony-ellenőrzési díj, indikátorrendszerben elért eredmények után járó díjazás, szakdolgozói kiegészítő díjazás és rezsitámogatási díjazás) körülbelül 4\%-a származik az ITR-ból [37, 38]. Ez elhanyagolhatónak tûnik a kártyapénz és fix díj 60\% körüli mértékéhez képest $[37,38]$, azonban a finanszírozás standardizált indikátorok értékelésén alapuló szétosztásával a bevétel közel 10\%-a származhatna az ITR-ból.

A továbbfejlesztett, standardizált indikátorok alkalmazásának hasznosságáról szóló eredmények azonban nem jelentik azt, hogy nincs szükség a nyers indikátorokra. Az ITR célja ugyanis a szolgáltatási hatékonyság javítása és annak biztosítása, hogy minél többen kapják meg az állapotuknak megfelelő ellátást az alapellátásban. Vagyis elengedhetetlen része a monitoringnak a szakmai ajánlások (célérték által definiált) megvalósulásának nyers gyakoriságokon alapuló értékelése, ami egyszerúen azt mutatja meg, hogy a betegek hány százaléka kapta meg a szükséges ellátást, azaz a beteg szempontjából értékeli az ellátás hatékonyságát.

Azonban, az ellátás hatékonyságának javítását a NEAK a vele szerződéses viszonyban álló háziorvos munkájának befolyásolásán keresztül tudja elérni. Ezért neki a háziorvosi munka hatékonyságát kell monitoroznia, és a többletfinanszírozás eszközei révén ennek a javulását kell ösztönöznie.

A jelenlegi ITR bemutatott továbbfejlesztésével kapcsolatos módszer kialakításának alapja az volt, hogy az orvos munkájának hatékonysága csak részben függ az 
orvos saját tulajdonságaitól (ismereteitől, attitűdjétől, elkötelezettségétől stb.). Jelentős részben az általa nem befolyásolható tényezőktől függ a praxisban elért hatékonyság [39, 40]. Az utóbbiak egy részére korrigáltuk az indikátorokat, de számos további, a háziorvos által nem befolyásolható tényezőre (a betegségek súlyossága, a beteg életmódja és együttmüködési készsége, a háziorvos neme és életkora) nem tudtuk korrigálni az indikátorokat, amelyek bevonása az indikátorképzésbe a monitoring hatékonyságának további javulását eredményezné.

Limitációként meg kell említeni, hogy a korrekciós faktorként bevont relatív iskolázottság a praxis által ellátott területre jellemző társadalmi-gazdasági státusz indikátor: az ellátottak egyéni szintû végzettségi adatainak felhasználásával tovább lenne javítható az indikátorok korrekciója.

Emellett a NEAK adataiban előforduló torzítás (a jelentett adatok minőségével kapcsolatos problémák) és az indikátorok definíciójával kapcsolatos szakmai problémák is hatással vannak az ITR hatékonyságára. Tekintettel arra, hogy a NEAK által jelenleg használt ITR is ezeket az adatokat és esetdefiníciókat használja, ez a torzítás az értékelés módszertanával kapcsolatos megállapításaink validitását nem befolyásolja, hiszen a jelenlegi rendszer és a standardizált indikátorokon alapuló módszer finanszírozási hatásának a különbségeit csak az eltérő értékelési módszertan okozza, a monitoring többi eleme ugyanaz a két rendszerben.

A korrigált indikátorok statisztikai értékelésén alapuló ITR, az adatfeldolgozás összetettsége miatt, első megközelítésben bonyolultnak tûnő értelmezést igényel. Valójában az eredmények interpretációja egyszerü: a korrigált indikátorok azt mutatják meg, hogy egy adott praxis a hasonló adottságú praxisok között milyen eredményességgel múködik, azaz jobb, rosszabb vagy átlagos teljesítményt sikerült elérnie. Ezek az indikátorok a praxis inherens - háziorvosi tevékenységtől független - sajátosságaiból adódó hatásokat kiküszöbölve, a háziorvosi munka hatékonysága szempontjából értékelik a teljesítményt. Emiatt arra az egyszerü kérdésre adnak választ, hogy: az ellátás javítása érdekében kell-e változtatni a háziorvos saját tevékenységén? Ez már könnyen értelmezhető a háziorvos, a vele szerződéses viszonyban álló önkormányzatok és az ellátott felnőttek számára is, ami megteremti az alapját annak, hogy az alapellátás hatékonyságát jelentős mértékben meghatározó helyi együttmúködések, a problémák korrekt feltárását követően, a megoldás érdekében, esetleg közösségi erőforrások bevonása révén valósuljanak meg. Az angol tapasztalat is bizonyítja, hogy egy evidenciákon alapuló célértékekkel kiegészített indikátorkészlet, megfelelő finanszírozással és visszajelzési rendszerrel társulva, képes javítani az ellátás minőségét, növeli a háziorvosok elégedettségét, csökkenti a betöltetlen praxisok számát és az egyenlőtlenségeket a hozzáférhetőség terén [33].

A valós személyes háziorvosi teljesítményt jobban tükröző standardizált indikátorokon alapuló értékelés és az erre épülő magasabb finanszírozás hozzájárulhat a háziorvosok továbbra is jobb teljesítményre való ösztönzéséhez. Tekintettel arra, hogy az ITR-ben jelenleg használt indikátorok olyan betegségek gondozásával kapcsolatosak, amelyek jelentős egészségveszteség és ezért jelentős népegészségügyi problémák forrásai, a gondozás hatékonyságának növelésével, a gondozottak egészségi állapotának javulásával a népegészségügyi helyzet javításához járulhatnak hozzá a háziorvosok jobb teljesítményük révén. Természetesen ehhez szükséges olyan jelentési rendszer kialakítása és fenntartása, amely az eredmények hozzáférhetőségét nemcsak a háziorvosok számára biztosítja, hanem az egészségpolitikai döntéshozók, a fenntartó önkormányzatok és az ellátottak számára is.

Elvileg a hazai jogi környezet is az érvényben lévő ITR folyamatos értékelése és a továbbfejlesztés irányába mutat, hiszen a 2010. évi CXXX., jogalkotásról szóló törvény $21 . \$(1)$ pontja szerint „A miniszter folyamatosan figyelemmel kíséri a feladatkörébe tartozó jogszabályok hatályosulását, és szükség szerint lefolytatja ... a jogszabályok utólagos hatásvizsgálatát" [41].

\section{Következtetés}

Vizsgálati eredményeink szerint a jelenlegi ITR célzott adatgyűjtést nem igénylő, meglévő adatok hasznosítására alapozott továbbfejlesztése a monitoring hatékonyságát több diszfunkcionális elem kiiktatása révén javíthatja. $\mathrm{Az}$ eddigi gyakorlatban alkalmazott nyers indikátorok mellett a statisztikailag értékelt és praxisjellemzőkre korrigált indikátorok alkalmazása indokolt lenne, mert a rendelkezésre álló finanszírozási eszközök felhasználásának hatékonyságát jelentős mértékben növelné, ezáltal javítaná az ellátás hatékonyságát. A javuló monitoring alkalmat teremtene arra is, hogy az ITR eredményei ne csak a háziorvosok, hanem szélesebb kör számára is elérhetők legyenek, ami az alapellátás helyi környezetében eredményezhetne kedvező, az ellátottak érdekét szolgáló változásokat.

Anyagi támogatás: A kézirat az $\mathrm{SH} / 8 / 1$ regisztrációs számú Svájci Hozzájárulás Program keretében támogatott, „Az egészségügy forrásainak felhasználásával népegészségügyi fókuszú alapellátás-szervezési modellprogram Virtuális Ellátó Központ támogatásával” program keretében és a GINOP-2.3.2-15-2016-00005. számú, „A magyar gazdaság versenyképességének növelése a lakosság egészségi állapotát javító népegészségügyi intervenciók célcsoportjainak és tartalmának azonosítása révén” kutatási pályázat támogatásával készült.

Szerzôi munkamegosztás: S. J.: A koncepció kidolgozása. P. A., K. N., S. V., V. F.: Az adatbázis létrehozása és az adatok statisztikai elemzése. S. J., P. A., P. M., C. Á., Á. R.: Az eredmények értelmezése. P. A., S. J.: A kézirat megszövegezése, az ábra és a táblázatok elkészítése. S. J., 
Á. R.: A kézirat végső változatának kialakítása. A cikk végleges változatát valamennyi szerző elolvasta és jóváhagyta.

Érdekeltségek: A szerzőknek nincsenek érdekeltségeik a cikkel kapcsolatban.

\section{Köszönetnyilvánítás}

A szerzők köszönetüket fejezik ki a Nemzeti Egészségbiztosítási Alapkezelő munkatársainak az elemzett adatbázis felépítéséhez nyújtott segítségükért.

\section{Irodalom}

[1] Braithwaite J, Hibbert P, Blakely B, et al. Health system frameworks and performance indicators in eight countries: a comparative international analysis. SAGE Open Med. 2017; 5: 2050312116686516

[2] Arah OA, Klazinga NS, Delnoij DM, et al. Conceptual frameworks for health systems performance: a quest for effectiveness, quality, and improvement. Int J Qual Health Care 2003; 15: 377-398.

[3] National Health Service (NHS). Quality and Outcomes Framework (QOF). Available from: http://www.nhsemployers.org/ sitecore/content/nhs confederation/home/confedl8 [accessed: July 18, 2018].

[4] National Health Service (NHS) Digital. Quality and Outcomes Framework 2016/17. Available from: https://qof.digital.nhs. uk/index.asp [accessed: July 18, 2018].

[5] National Committee on Quality Assurance (NCQA). HEDIS \& Quality Measurement. Available from: http://www.ncqa.org/ hedis-quality-measurement [accessed: July 16, 2018].

[6] Canadian Institute for Health Information (CIHI). Primary Health Care. Available from: https://www.cihi.ca/en/primaryhealth-care [accessed: July 16, 2018]

[7] Canadian Institute for Health Information (CIHI). Pan-Canadian Primary Health Care Indicator Update Report 2012. Available from: https://secure.cihi.ca/free_products/Pan-Canadian_PHC_Indicator_Update_Report_en_web.pdf [accessed: July $16,2018]$.

[8] Cashin C. Major Developments in Results-Based Financing (RBF) in OECD Countries: Country Summaries and Mapping of RBF Programs. New Zealand: Primary Health Organization (PHO) Performance Program 2011. Available from: https:// www.rbfhealth.org/sites/rbf/files/Case\%20study\%20New\%20 Zealand\%20PHO.pdf [accessed: July 18, 2018].

[9] Primary Health Organization (PHO) Performance Programme Stack - Health Quality Measures New Zealand. Available from: https://www.hqmnz.org.nz/library/PHO_Performance_Programme_Stack [accessed: October 18, 2018].

[10] Australian Commission on Safety and Quality in Health Care. Practice-level indicators of safety and quality for primary health care. Available from: https://www.safetyandquality.gov.au/ourwork/indicators/practice-level-indicators-of-safety-and-qualityfor-primary-health-care/ [accessed: October 18, 2018].

[11] Australian Commission on Safety and Quality in Health Care. Practice-level indicators of safety and quality for primary health care specification 2012. Available from: https://www.safetyandquality.gov.au/wp-content/uploads/2012/02/Practice-levelindicators-for-primary-health-care-specification-V1.0-October-2012.pdf [accessed: October 18, 2018].

[12] Campbell SM, Braspenning J, Hutchinson A, et al. Research methods used in developing and applying quality indicators in primary care. BMJ 2003; 326: 816-819.
[13] NHS Employers. Quality and Outcomes Framework. The full set of indicators in 2017/2018 - England 2017. Available from: http://www.nhsemployers.org/-/media/Employers/Documents/Primary-care-contracts/QOF/2017-18/201718-Quality-and-outcomes-framework-summary-of-changes.pdf?la=en\&h ash=D08AB4F7CE88F5D76E836E2F57FB6DCF241C8BC6 [accessed: July 18, 2018].

[14] Canadian Institute for Health Information. Primary Health Care in Canada: A Chartbook of Selected Indicator Results, 2016 Methodology Notes 2016. Available from: https://www.cihi. $\mathrm{ca} /$ sites/default/files/methodology_notes_for_phc_chartbook_indicators_en_web.pdf [accessed: August 3, 2018].

[15] Healthcare Effectiveness Data and Information Set (HEDIS). The State of Health Care Quality - Persistence of Beta-Blocker Treatment After a Heart Attack. Available from: http://www. ncqa.org/report-cards/health-plans/state-of-health-carequality/2017-table-of-contents/beta-blockers [accessed: July $16,2018]$.

[16] National Institute for Quality- and Organizational Development in Healthcare and Medicines. Hungarian Health System Scan 2012. Available from: https://era.aeek.hu/zip_doc/hirlevel_ en/2012/HHSS-2012\%20February.pdf [accessed: July 16, 2018].

[17] National Institute for Quality- and Organizational Development in Healthcare and Medicines. Hungarian Health System Scan 2014. Available from: https://era.aeek.hu/zip_doc/hirlevel_ en/2014/HHSC-2014-1-k.pdf [accessed: July 16, 2018].

[18] Indicator-based performance evaluation of family doctors. [A háziorvosok indikátor alapú teljesítményértékelése.] Available from: http://www.neak.gov.hu/data/cms983769/HAZIORVOSI_INDIKATOROK.pdf [accessed: July 16, 2018]. [Hungarian]

[19] Indicator-based performance evaluation of family doctors from 1st of April 2011. [A háziorvosok indikátor alapú teljesítményértékelése 2011. április 1-től.] Available from: http://www. neak.gov.hu/data/cms983767/HAZIORVOSI_INDIKATOROK_20110401.pdf [accessed: July 16, 2018]. [Hungarian]

[20] Indicator-based performance evaluation of family doctors from 1st of April 2012. [A háziorvosok indikátor alapú teljesítményértékelése 2012. április 1-től.] Available from: http://www. neak.gov.hu/data/cms983759/HAZIORVOSOK_INDIKATOR_ALAPU_TELJESITMENY_20120401.pdf [accessed: July 16, 2018]. [Hungarian]

[21] Indicator-based performance evaluation of family doctors from lst of November 2012. [A háziorvosok indikátor alapú teljesítményértékelése 2012. november 1-től.] Available from: http:// www.neak.gov.hu/data/cms1000843/Haziorvosi_indikatorok_2012._november_1_tol.pdf [accessed: July 16, 2018]. [Hungarian]

[22] Indicator-based performance evaluation of family doctors from April 2014. [A háziorvosi szolgálatok indikátor alapú teljesítményértékelése 2014. áprilistól.] Available from: http://www. neak.gov.hu/data/cms1002602/HAZIORVOSOK_INDIKATOR_ALAPU_TELJESITMENY_201404.pdf [accessed: July 16, 2018]. [Hungarian]

[23] Indicator-based performance evaluation of family doctors from September 2017. [A háziorvosi szolgálatok indikátor alapú teljesítményértékelése - 2017. szeptember.] Available from: http:// www.neak.gov.hu/data/cms1018677/Haziorvosok_indikator_ alapu_teljesitmeny_NEAK_201709.pdf [accessed: July 16, 2018]. [Hungarian]

[24] Indicator-based performance evaluation of family doctors from December 2017. [A háziorvosi szolgálatok indikátor alapú teljesítményértékelése - 2017. december.] Available from: http:// www.neak.gov.hu/data/cms1018678/Haziorvosok_indikator_ alapu_teljesitmeny_NEAK_201712_2.pdf [accessed: July 16, 2018]. [Hungarian] 
[25] Indicator-based performance evaluation of family doctors from February 2018. [A háziorvosok indikátor alapú teljesítményértékelése - 2018. február.] Available from: http://www.neak.gov. $\mathrm{hu} /$ data/cms1018679/Haziorvosok_indikator_alapu_teljesitmeny_NEAK_201802.pdf [accessed: July 16, 2018]. [Hungarian]

[26] Government Decree No. 43/1999. (III. 3) on the detailed rules for financing health services from the Health Insurance Fund. [43/1999. (III. 3.) Korm. rendelet az egészségügyi szolgáltatások Egészségbiztosítási Alapból történő finanszírozásának részletes szabályairól.] Available from: http://njt.hu/cgi_bin/ njt_doc.cgi?docid=40568.354064 [accessed: May 25, 2018]. [Hungarian]

[27] Decree No. 11/2011 (III. 30.) of the Ministry of National Resources on the indicator-based performance evaluation of general practitioners and certain rules for assessing doctors' orders. [11/2011. (III. 30.) NEFMI rendelet a háziorvosok indikátor alapú teljesítményértékeléséről és az orvosok gyógyszerrendelése értékelésének egyes szabályairól.] Available from: http://njt. hu/cgi_bin/njt_doc.cgi?docid=137366.333472 [accessed: May 25, 2018]. [Hungarian]

[28] Kolozsvári LR, Rurik I. Quality evaluation of primary care service performance. What are the problems with the recent Hungarian primary care indicators? [A háziorvosok teljesítményének minőségi értékelése. Mi a probléma a háziorvosi indikátorokkal?] Orv Hetil. 2016; 157: 328-335. [Hungarian]

[29] Campbell SM, Braspenning J, Hutchinson A, et al. Research methods used in developing and applying quality indicators in primary care. BMJ 2003; 326: 816-819.

[30] Sándor J, Pálinkás A, Vincze F, et al. Association between the general practitioner workforce crisis and premature mortality in Hungary: cross-sectional evaluation of health insurance data from 2006 to 2014. Int J Environ Res Public Health 2018; 15: 1388.

[31] Samuels SJ, Beaumont JJ, Breslow NE. Power and detectable risk of seven tests for standardized mortality ratios. Am J Epidemiol. 1991; 133: 1191-1197.

[32] NHS Employers. Changes to QOF 2018/19. Available from: https://www.nhsemployers.org/QOF201819 [accessed: October 16, 2018].

[33] Doran T, Roland M. Lessons from major initiatives to improve primary care in the United Kingdom. Health Aff. 2010; 29: $1023-1029$
[34] Cashin C, Chi YL, Smith PC, et al. (eds.) Paying for performance in health care: Implications for health system performance and accountability. Open University Press, McGraw-Hill Education, London, 2014.

[35] Kolozsvári LR, Orozco-Beltran D, Rurik I. Do family physicians need more payment for working better? Financial incentives in primary care. Aten Primaria 2014; 46: 261-266.

[36] Appropriation and payment data of curative and preventive care in Hungary 2017-2018. [Gyógyító-megelőző ellátások 20172018. évi előirányzata és kifizetési adatai.] Available from: http://www.neak.gov.hu/felso_menu/szakmai_oldalak/publikus_forgalmi_adatok/gyogyito_megelozo_forgalmi_adat?pagenum $=1$ [accessed: March 21, 2019]. [Hungarian]

[37] Basic fees and nationally aggregated performance data broken down by month. [Alapdíjak és országosan összesített teljesítményadatok havi bontásban.] Available from: http://neak.gov.hu/ felso_menu/szakmai_oldalak/gyogyito_megeleozo_ellatas/ adatbazisok/statisztikai_adatok [accessed: March 21, 2019]. [Hungarian]

[38] Frequently asked question (FAQ) for genereal practitioners. [Gyakran ismételt kérdések (GYIK) leendő és gyakorló háziorvosok részére.] Available from: http://www.neak.gov.hu/data/ cms1003074/GYIK_HSZ_201708.pdf [accessed: March 21, 2019]. [Hungarian]

[39] Sándor J, Nagy A, Földvári A, et al. Delivery of cardio-metabolic preventive services to Hungarian Roma of different socio-economic strata. Fam Pract. 2017; 34: 83-89.

[40] Sándor J, Nagy A, Jenei T, et al. Influence of patient characteristics on preventive service delivery and general practitioners' preventive performance indicators: a study in patients with hypertension or diabetes mellitus from Hungary. Eur J Gen Pract. 2018; 24: 183-191.

[41] Act CXXX of 2010 on Legislation. [2010. évi CXXX. törvény a jogalkotásról.] Available from: https://net.jogtar.hu/jogszabaly?docid=A1000130.TV [accessed: May 25, 2018]. [Hungarian]

(Sándor János dr., Debrecen, Pf. 400, 4002 e-mail: sandor.janos@sph.unideb.hu)

\section{„Feliciter sapit, qui alieno pericula sapit." (Plautus) (Más kárán okul a bölcs.)}

A cikk a Creative Commons Attribution 4.0 International License (https://creativecommons.org/licenses/by/4.0/) feltételei szerint publikált Open Access közlemény, melynek szellemében a cikk bármilyen médiumban szabadon felhasználható, megosztható és újraközölhetö, feltéve, hogy az eredeti szerző és a közlés helye, illetve a CC License linkje és az esetlegesen végrehajtott módosítások feltüntetésre kerülnek. (SID_1) 